\title{
Determination of Heavy Metal Genotoxicity and their Accumulation Pattern in Different Fish Organs of Selected Fish Species collected from the Asa River, Ilorin, Kwara State, Nigeria
}

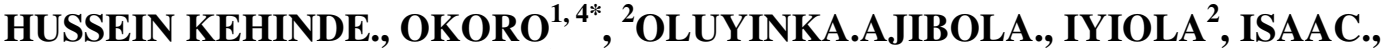 SIMON $^{1}$ SEGUN O., OLADIPO ${ }^{3}$}

\author{
${ }^{I}$ Material and Environmental-Analytical Research Group, Department of Industrial Chemistry, Faculty of Physical Sciences, University of \\ Ilorin, P.M.B. 1515. Ilorin, Nigeria. \\ ${ }^{2}$ Cell Biology and Genetics Unit, Department of Zoology, Faculty of Life Sciences, University of Ilorin, P.M.B. 1515. Ilorin, Nigeria. \\ ${ }^{3}$ Zoology Units, Department of Biosciences and Biotechnology, Kwara State University, Malete, Nigeria. \\ 4.Analytical-Environmental and Membrane Nanotechnology Research Group, Department of Applied chemistry, University of \\ Johannesburg, P.O. Box 17011, Doornfontein 2028, Johannesburg, Republic of South Africa. \\ Corresponding author's Email: okoroowo@yahoo.com; hkoadeola@gmail.com
}

\begin{abstract}
This study investigated bioaccumulation of heavy metals and cytogenotoxic effects that could result from exposure of fish to heavy metals in the Asa River, Ilorin, Nigeria. The three different fish species, Tilapia zilli, Oreochromis niloticus and Sarotherodon galilaeus were obtained from the Asa River and the fourth species, Clarias gariepinus was cultured in the laboratory to serve as control. The fish organs; bone, gills, kidney and liver from the four fish species were carefully dissected for the determination of some heavy metals. The results showed that the metal concentration levels were in the order $\mathrm{Pb}>\mathrm{Cr}>\mathrm{Zn}>\mathrm{Cd}$. The highest lead concentration value was observed in the gills of Tilapia fish. The lowest level of $\mathrm{Cd}$ was observed in the bone tissue of Oreochromis niloticus. The values of heavy metals found in the cultured fish species were very low in concentration compared to the ones sourced from Asa River. Micronuclei and frequencies of nuclear abnormalities were assessed in the blood erythrocytes of both laboratory cultured fish and the ones obtained from Asa River. Significant differences $(\mathrm{P}<0.05)$ were observed for mean frequencies of micronucleus induction in the blood erythrocytes of Oreochromis niloticus, Sarotherodon galilaeus. As for other nuclear abnormalities, significant differences $(\mathrm{P}<0.05)$ were observed for mean frequencies in the blood erythrocytes, gills and liver of Tilapia zilli and Oreochromis niloticus. Genotoxicity results in this study showed that the Asa river water contains genotoxic metals say be responsible for the micronucleus and nuclear abnormalities observed in the aquatic environment. CJASEM http://dx.doi.org/10.4314/jasem.v20i3.28
\end{abstract}

Keywords: Genotoxicity, bioaccumulation, organs, cultured, metals, fish organs

Heavy metals are mostly stored in rock, some are beneficial to living organisms, while some are not. Metals become highly toxic when they are present in higher concentrations (Ibok et al., 1989). The removal of heavy metals completely upon gaining entrance into the environment becomes difficult (Aderinola, 2009). Water contamination by heavy metals may pose adverse effects on the ecological balance of natural water bodies, including loss of aquatic diversity (Vosyliene and Jankaite, 2006). Metals gain access into the ecosystem through multifarious sources like effluents from industries, agricultural runoff and untreated sewage (Bhuvaneshwani et al., 2012). In the course of metal mobility, they get distributed in the water body, suspended solids, and sediments (Enieji et al., 2011). Metal contamination in aquatic ecosystem is considered to be unsafe not only for the aquatic lives but also for the human beings (Mendil and Uluozlu, 2007). In Nigeria and globally, economic development depends on industrialization which serves as an important life wire required for development and for increasing the standard of living of humans and their well-being (Olayinka, 2013).

Contamination of aquatic resources with different kinds of pollutants has become a matter of concern over the past few decades (Diriliger, 2001; Vulukuru, 2005; Yousafzai and Shakoori, 2006; Narayanar and Vinodhiri, 2008; Fatoki et al., 2012; Okoro et al., 2013; Okoro et al., 2014a; Okoro et al., 2014b). In surface waters fish are important links in the food chains, and may often accumulate large amounts of certain metals above the levels in the aquatic environment (Deb and Santra, 1997; Farkas et al., 2002; Ambedkar and Muniyan, 2011). As a result, fish are often used as indicators of heavy metal contamination because they occupy high trophic levels and are an important source of food (Blasco et al., 1998; Agah et al., 2009). Fish are widely consumed not only in Nigeria but in many parts of the world and polluted fish may harm human health 
(Zhang et al., 2007). Studies have revealed that fishes assimilate these heavy metals through ingestion of suspended particulates, food materials or through constant ion exchange processes of dissolved metals across the lipophilic membranes such as the gills, or through adsorption of dissolved metals onto tissue and membrane surfaces (Oguize, 1999; Oguzie and Okosodo 2008).

Various factors including season, physicochemical properties of water, habitat, age and physiological condition of fish play a significant role in accumulation of metals by fish (Kargin, 1996). Metal bioaccumulation is a major route through which increased levels of the pollutants are transferred through food chains and this creates public health problems when human beings are involved in the food chain (Otitoloju, 2002). Many related studies have been carried out to evaluate the level of metal bioaccumulation in various organs of fish since it has been known as one of the major and richest protein sources and unsaturated omega-3 fatty acid sources for humans (Elleta et al., 2003; Abdel-Baki et al., 2011; Ambedkar and Muniya, 2011; Enieji et al., 2011; Bhuvaneshwari et al., 2012; Yousafzai et al., 2012; Ahmed and Omar, 2013; Olayinka, 2013; Beetsech and Abrahams, 2013; Shivakuman et al., 2014 ). Genetic and molecular biomarkers such as micronucleus and comet assays are reliable indicators of pollution and environmental contamination. Micronucleus assay have been used for assessing the potential genotoxicity of various chemicals or industrial effluents using different animals (AI-Sabti and Metcalfe, 1995; Nwani et al., 2011; Bücker et al., 2012;, Nwani et al., 2013). This assay is applicable for environmental biomonitoring because it is reliable and sensitive enough to detect any nuclear lesions caused by exposure of living organisms such as fish and mice to potentially genotoxic chemicals.

In this study, micronucleus assay (MN) was used to evaluate the extent of genetic damage that may have been caused by heavy metal bioaccumulation in the organs of fishes obtained from e polluted Asa River, Ilorin, Nigeria. MN assay is a reliable and potent tool that has been extensively used to assess genotoxicity in aquatic animals (Bolognesi and Hayashi., 2011) including fishes (Ayllon and Garcia-Vazquez, 2000; Martinez et al., 2005; Talapatra and Banerjee., 2007; Yadav and Trivedi, 2009). Fishes are excellent specimens sensitive for the evaluation of the genotoxicity (Yadav and Trivedi, 2009). There is overwhelming evidence from previous studies that heavy metal such as copper is capable of inducing genomic instability in mammals (Linder, 2001) and even arsenic induces micronuclei in human (Martinez et al., 2005). For example, study carried out by Yadav and Trivedi (2009) have reported a significant induction of micronucleus upon sublethal exposure of heavy metals to Channa punctata. Similarly, exposure of fish to sublethal concentration of
Mercury (II) also causes significant induction of micronuclei over five treatment periods (Yadav and Trivedi, 2009).

There is documented evidence that the Asa River is polluted with appreciable amounts of heavy metals such as manganese, zinc, iron, and lead (Eletta et al., 2003) but there is no published literature available on the genotoxic effects of bioaccumulated heavy metals on fish found in the Asa River. The objectives of the present study were to determine heavy metal genotoxicity and the accumulation pattern in different fish organs viz and viz, muscle, bone tissue, gills and liver of selected fish species collected from the Asa River.

\section{MATERIALS AND METHODS}

Sampling Area and Sample Collection: Sampling was from Asa River in Ilorin, Kwara State. Ten individuals each of different fish species (Tilapia zilli, Oreochromis niloticus and Sarotherodon galilaeus) were obtained from Asa River with the help of local fishermen and the African catfish (Clarias gariepinus) was cultured in the laboratory. Fishes of average sizes were collected in order to avoid the possible error due to size differences. All fishes were transported in a $20 \mathrm{~L}$ open water container to the laboratory, where they were disinfected with a dip of $2 \% \mathrm{KMnO}_{4}$ for 15 minutes and then washed with borehole water to remove debris. The catfish used as control were obtained from a local fish farm (fish farms, GRA, Ilorin, Nigeria) and were of approximately the same body weight and length as the ones used for the test. Healthy and live specimens were given prophylactic treatment by bathing in formalin $(0.4 \%)$ for $10 \mathrm{~min}$ and $\mathrm{KMnO}_{4}$ solution (1 $\mathrm{mg} / \mathrm{L}$ ) for $15 \mathrm{~min}$ to keep away from any dermal infections and were then acclimatized for 10 days in large glass aquaria containing tap water. Thereafter, fishes were sacrificed to remove gills, liver, kidney, bone, and muscle tissue. These samples were transferred into sterile sample bottles, labelled and kept for digestion and analysis of bioaccumulation of heavy metals in the fish samples.

Chemicals and Reagents: All reagents were of analytical reagent grade. Double deionized water was used for all dilutions. Nitric acid, $\mathrm{HNO}_{3}(65 \%)$ and hydrogen peroxide $(30 \%)$ were of ultrapure quality purchased from Merck, Darmstadt, Germany. The element standard solutions from Merck Company to make the calibration were prepared by diluting the stock solutions of $1000 \mathrm{mg} / \mathrm{L}$ of each element.

Digestion of Fish Samples for Heavy Metal Determination: The method of Palermo et al. (2015) was adopted with little modifications. Briefly, heavy metal content was quantified in gill, liver, kidney and bone after drying at $60^{\circ} \mathrm{C}$. Dry tissue samples were fully digested $(1: 10 \mathrm{w} / \mathrm{v})$ in $5 \mathrm{~N}^{-} \mathrm{HNO}_{3}$ (Suprapur, 
Merck) at $60^{\circ} \mathrm{C}$. Samples were then centrifuged $(14,000 \mathrm{~g}, 20 \mathrm{~min})$ and the supernatants were then used for heavy metal determination by using an Atomic Absorption Spectrophotometer (Perkin Eelmer E. Analyst, 2000, USA).

Micronucleus and Genotoxicity Test: The MN test was performed according to the methods of Tolbert et al., (1992) and Al-sabti et al., (1995) with some minor modifications. Fresh blood was collected from a caudal puncture into a heparinised syringe. Blood samples from the tail were smeared on clean, grease free frosted glass slides. Slides were fixed in methanol for 10 minutes, left to air-dry at room temperature overnight for 12 hours and then fixed in absolute methanol for 15 minutes by dipping the film briefly in a jar containing absolute methanol. After fixing, the same slides were stained in aqueous Giemsa $(5 \%)$ for 10 minutes (Palhares and Grisola, 2002). The Giemsa stain was removed after 20 minutes and the slides were air dried in a vertical position. The slides were then covered with a cover slip and fixed with Canada balsam. For each group, two microscopic slides were prepared from each animal. 1000 nuclei were scored per slide to determine nuclear lesions and micronuclei in the erythrocytes. The frequency of MN was determined following previously reported examination criteria (K“onen, 2007; Vera-Candioti et al., 2010; VeraCandioti, et al., 2013). Micronuclei appear as chromatin masses resulting from chromosome fragments or intact whole chromosomes lagging behind in the anaphase stage of cell division and due mainly to exposure of cells to toxic substances.

Statistical analysis: Frequencies of induction of MN erythrocytes and other nuclear abnormalities were determined in 1000 cells scored per slide from peripheral blood. SPSS 16.0 was used for the statistical analysis. Results are expressed as mean \pm SE. A two-way analysis of variance (ANOVA) and Duncan's Multiple Range Test (DMRT) were used to analyze the data with the level of statistical significance estimated at $\mathrm{P}<0.05$.

\section{RESULTS AND DISCUSSION}

The trend of metal accumulation in fish organs is different amongst species (Figure 1-4). The difference in the levels of accumulation in different organs of a fish can primarily be attributed to the variations in the physiological role of each organ. Other factors such as regulatory ability, behaviour and feeding habits may play an important role in the accumulation differences in the different organs (Baldisserotto et al., 2005). In addition, the chemical nature of the metals, ionic strength and $\mathrm{pH}$ tend to be a master variable in the accumulation process. In acidic conditions, there are enough hydrogen ions to occupy many of the negatively charged surfaces and little space is left to bind heavy metals. Therefore, more heavy metals are found in the soluble phase. The soluble form of heavy metals is thought to be more harmful because it is more easily transported and more readily available to aquatic organism (Baldisserotto et al., 2005) Metal concentrations in different organs of fishes in $\mathrm{mg} / \mathrm{kg}$ are shown Figure $1-4$, respectively.

Embryonic development, suppressed reproduction and inhibition of growth, increased mucous formation, neurological problems, enzyme inhibition and kidney dysfunction are some of the biological effects resulting from sublethal lead exposure (Rompala et al., 1984). Lead was the metal with higher concentration of $3.94 \mathrm{mg} / \mathrm{kg}$ as recorded in this study. According to Elleta et al., (2004), the lead concentration in the fish samples from Asa River was $4.41 \mathrm{mg} / \mathrm{kg}$. This shows that this result is in conformity with previous research findings carried out on Asa River.

The highest concentration of lead $(0.53 \pm 0.0058$ $\mathrm{mg} / \mathrm{kg}$ ) was detected in the gill tissue of Tilapia (Figure 1), while the lowest concentration levels of lead $(0.12 \pm 0.001 \mathrm{mg} / \mathrm{kg})$ was found in the bone tissue of Tilapia zilli (Figure 1). The obtained result is in agreement with previous observation made by Deb and Fuka-Shina (1999) that metals may be high in concentrations in the gills and intestine. The concentration of lead detected in gills of Tilapia fish was lower than the maximum permissible limit of the (WHO/FAO, 2011). A similar result was obtained in a related study carried out by Shirakumar et al., (2014). The increased lead concentrations in fish samples near to the maximum permissible limit shows potential health risks for human consumption. The pattern of metal accumulation depends on the fish species and its habitat or sampling area (Shirakumar et al., 2014).

The highest concentration of cadmium was $0.38 \pm$ $0.011 \mathrm{mg} / \mathrm{kg}$ in the gill tissue of Tilapia fish (Figure 1 ), while the lowest concentration levels for cadmium $(0.01 \pm 0.007 \mathrm{mg} / \mathrm{kg})$ was found in the bone tissue of Oreochromis niloticus (Figure 2). For cadmium the reverse is the case in this study, the obtained gradient concentration value was above WHO/FAO, (2011) maximum permissible limit of $0.2 \mathrm{~g}$. Cadmium is a highly toxic non- essential heavy metal and it does not have a role in biological processes of living organisms. Thus even at low concentration, cadmium could be harmful to living organisms (Ambedkar, 2011). The cadmium concentration was indicative of high potential health effects to the majority of the patronizing fish consumer population at the study area. The highest concentration of cadmium in the fish species was above the (WHO/FAO, 2011), maximum permissible limit of $0.2 \mathrm{mg} / \mathrm{kg}$ for food samples 
The highest concentration of chromium $(0.49 \pm 0.025$ $\mathrm{mg} / \mathrm{kg}$ ) was found in the gill tissue of Oreochromis niloticus fish (Figure 2) while the lowest concentration of chromium $(0.11 \pm 0.004 \mathrm{mg} / \mathrm{kg})$ was found in the kidney tissue of Oreochromis niloticus (Figure 2). In this study, insignificant concentrations of chromium were accumulated by in the tissues (gills and kidney). Similar observation was recorded in Olayinka et al., (2013 on Asa River, Somero et al., (1997); Allen et al., (1998). Lack of Cr results in impaired growth and disturbances in glucose, lipid and protein metabolism (Calabrese, 1985). $\mathrm{Cr}$ is an essential trace metal and the biologically usable form of $\mathrm{Cr}$ plays an essential role in glucose metabolism. The maximum guideline of $15-17 \mathrm{mg} / \mathrm{kg}$ stipulated by (USFDA, 1993), was however, higher than the concentrations of $\mathrm{Cr}$ measured in all the fish samples, hence the samples are safe for human consumption.

The highest concentration of Zinc $(0.39 \pm 0.019$ $\mathrm{mg} / \mathrm{kg}$ ) was found in the gill tissue of Oreochromis niloticus (Figure 2). The lowest concentration level of Zinc $(0.11 \pm 0.004 \mathrm{mg} / \mathrm{kg})$ was detected in the kidney tissue of Sarotherodon galilaeus (Figure 3).

Zinc concentration level in the fish species which was found to fall within the (WHO/FAO, 2011), maximum permissible limit of $40 \mathrm{mg} / \mathrm{kg}$ for food samples and the consumers are not in any potential health risk, (WHO/FAO, 2011). The concentration of zinc in the selected fish samples were due to the presence of the large number of agricultural activities, releasing metals that ultimately find their way into the ambient environment through leaching or runoff (Burden et al, 1998). The high level of zinc in the gill tissues can possibly be due to the fact that fish gills play a distinct role in metal uptake from the environment. Highest zinc deposition $(0.39 \pm 0.029$ $\mathrm{mg} / \mathrm{kg}$ ) was found in gills of Oreochromis niloticus and lowest concentration $(0.11 \pm 0.04 \mathrm{mg} / \mathrm{kg})$ was found in kidney tissue of Sarotherodon galilaeus.

In this study, the patterns of metal concentrations in Tilapia fish were $\mathrm{Pb}>\mathrm{Cr}>\mathrm{Cd}>\mathrm{Zn}$ while for Oreochromis niloticus, the metal concentrations were $\mathrm{Pb}>\mathrm{Cr}>\mathrm{Zn}>\mathrm{Cd}$ and Sarotherodon galilaeus. were $\mathrm{Pb}>\mathrm{Cr}>\mathrm{Zn}>\mathrm{Cd}$. The pattern of metal concentrations in catfish was $\mathrm{Pb}>\mathrm{Cr}>\mathrm{Zn}>\mathrm{Cd}$. Higher metal concentrations in the gills could be due to the element complexion with the mucus that is virtually impossible to completely remove from the gill lamellae before being prepared for analysis (Barron and Albeke, 2000). Furthermore, the adsorption of metals onto the gills surface as the first target for pollutants in water could also be a major factor in the total metal levels of the gill. Organs such as the gills are metabolically active parts that can bioaccumulate heavy metals in higher levels, as shown in various species of Cyprinus (Khail and Faragallah, 2008). Deb and Fukushima (1999), confirm this by reporting that metals may be in high concentrations in gill, liver, kidney and bone tissue of the selected fish samples.

Comparing the bioaccumulation of the heavy metals in the kidney and liver of the selected fish samples collected from the Asa River (Tilapia zilli, Oreochromis niloticus and Sarotherodon galilaeus ) and that of $C$. gariepinus which was cultured in the laboratory, a significant difference was observed in the patterns of their bioaccumulations. The bioaccumulation of heavy metal in catfish is lower compared to Tilapia zilli and Sarotherodon galilaeus because it was cultured under laboratory conditions using borehole water which was changed daily. On the other hand, Tilapia zilli, Oreochromis niloticus and Sarotherodon galilaeus have higher concentration of metals accumulated in their organs possibly due to the discharge of sewage from industries and large agricultural activities carried out in the Asa River. It is also not unlikely that the sediment of this river may contain different heavy metal compositions. The concentrations of heavy metals detected in samples of the three fish species were quite varied. Lead and Cadmium found in the fish samples were above the maximum permissible limits as per the WHO/FAO guideline standards limits.

The concentration of heavy metals found in the organs of the cultured fish species was of low value compared to that from Asa River. High concentrations of the heavy metals measured in the fish tissues sourced from Asa River were attributed to probable high influx of metals as a result of pollution from the agriculture activities, municipal and industrial wastes leachate intrusion, thereby, increasing the potential bioavailability to the fish and also posing the associated risks of affecting the quality of human health, particularly the most populous consumers in the long run. In this study, it was observed that metal deposition was mostly found in gill tissue, this could be due to their proximity to the external environment and their ionic regulatory tendencies could serve as a depot tissue, since metal uptake may exceed eliminations (Allen et al., 1988; Kuroshima, 1992). 


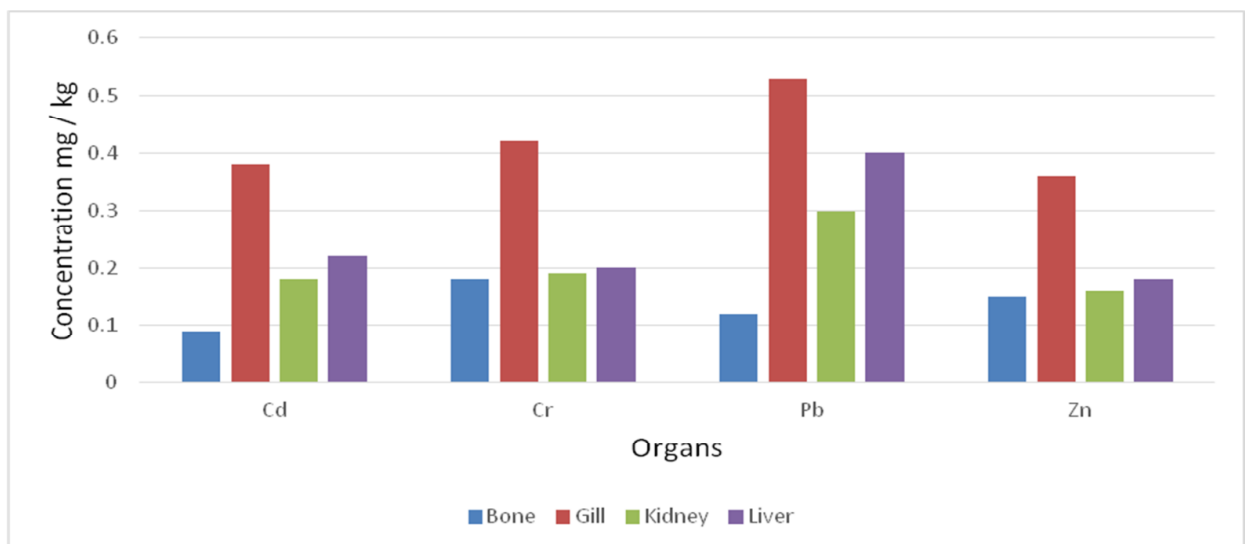

Fig 1: Mean concentration of heavy metals detected in bone, gills, kidneys and liver tissues of Tilapia zilli

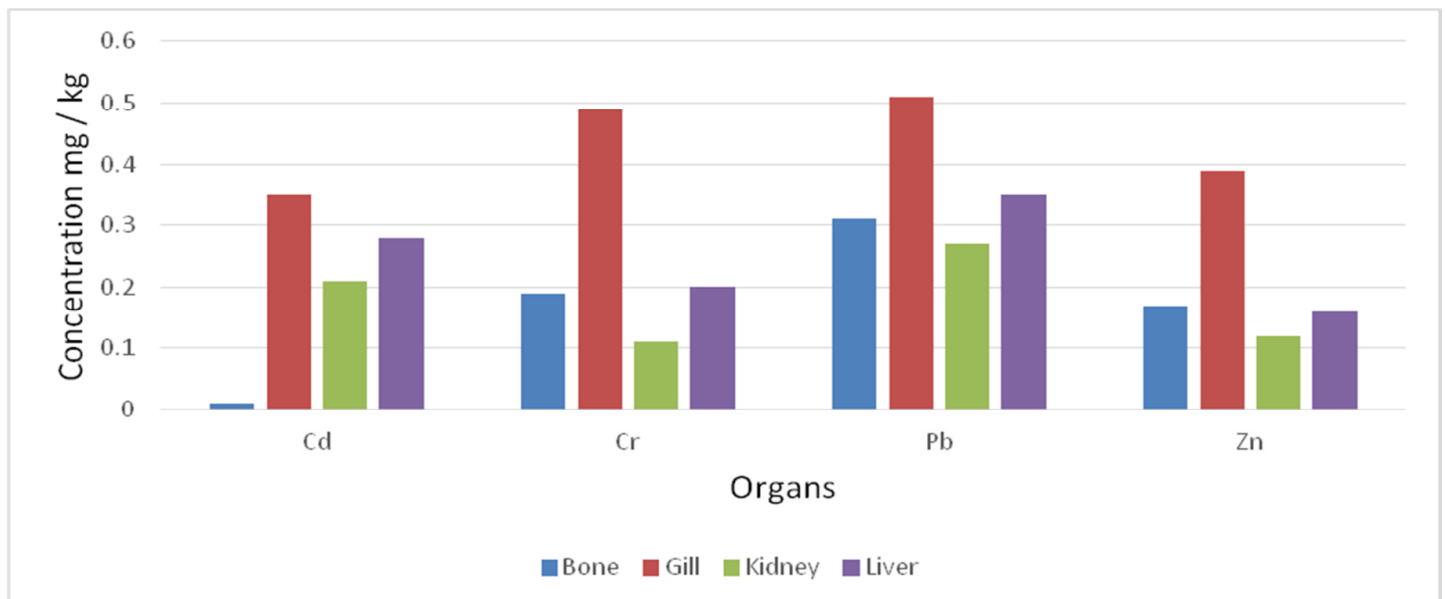

Fig 2: Mean concentration of heavy metals detected in bone, gills, kidneys and liver tissues of Oreochromis niloticus.

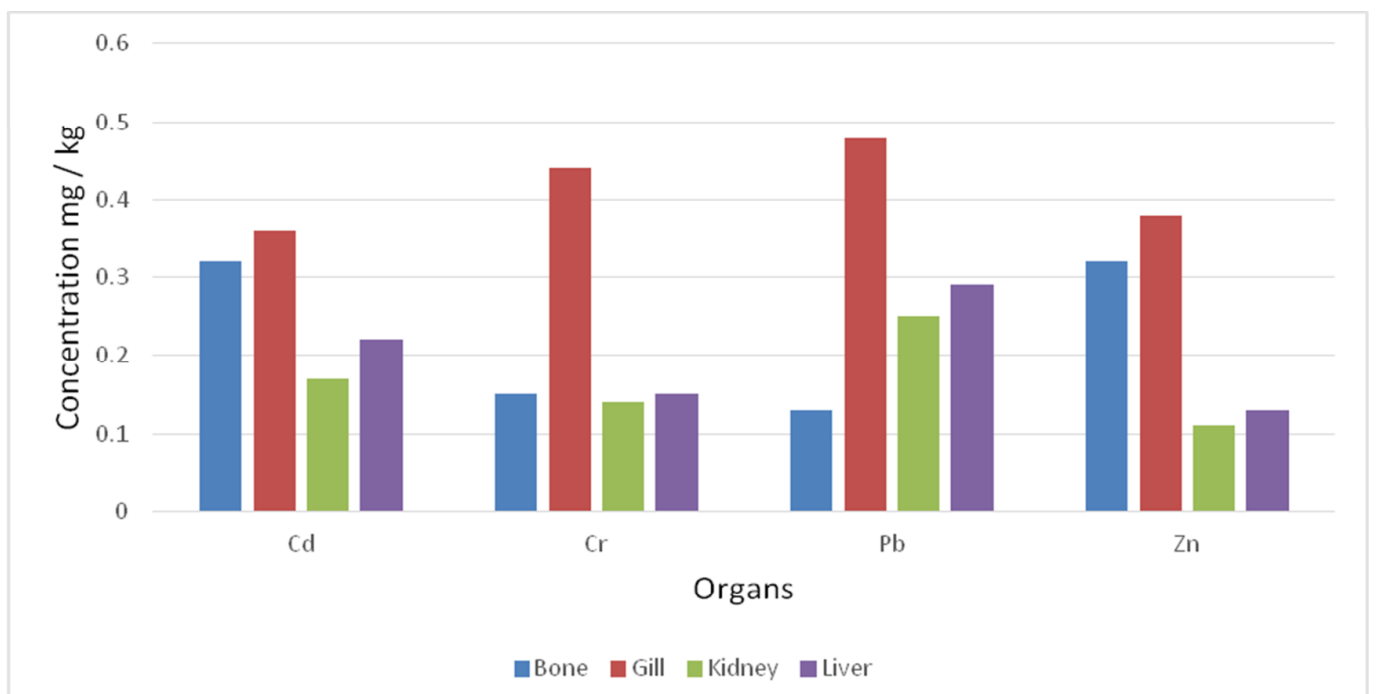

Fig 3: Mean concentration of heavy metals detected in bone, gill, kidney and liver tissues of Sarotherodon galilaeus 


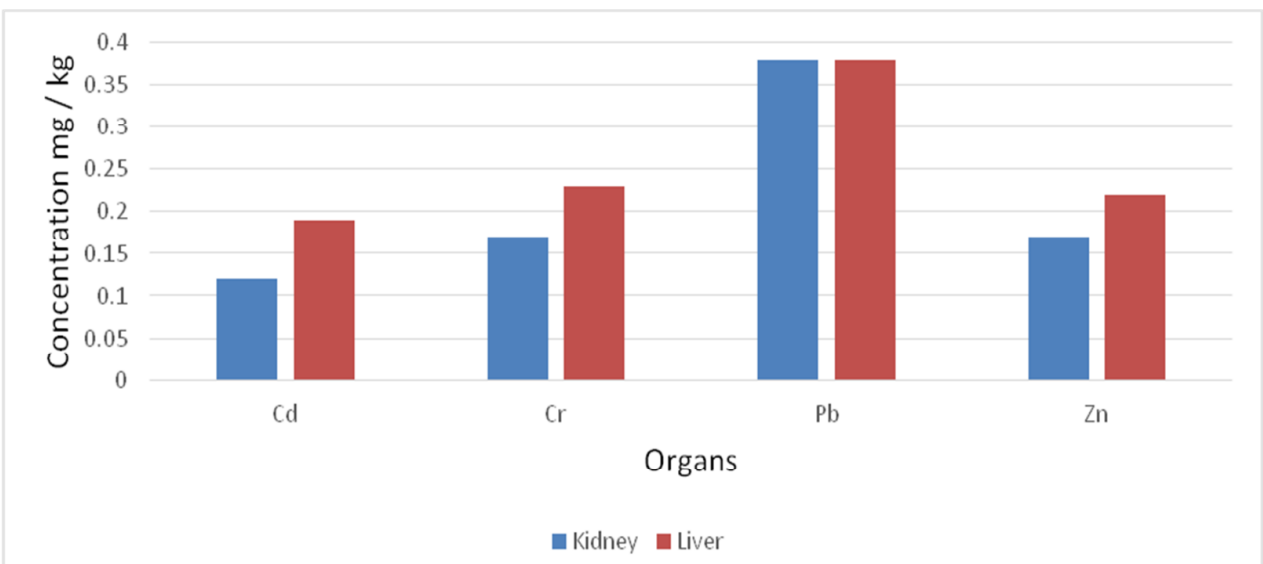

Fig 4: Mean concentration of heavy metals detected in kidney and liver tissues of Clarias gariepinus

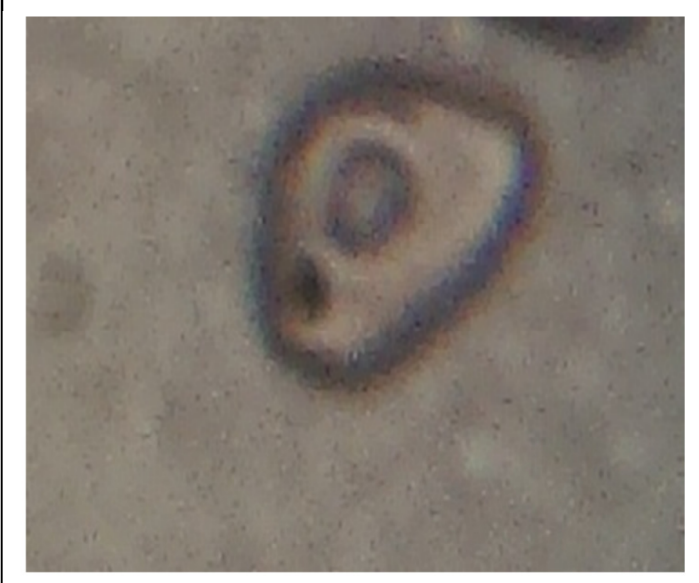

Micronucleus $\times 100$

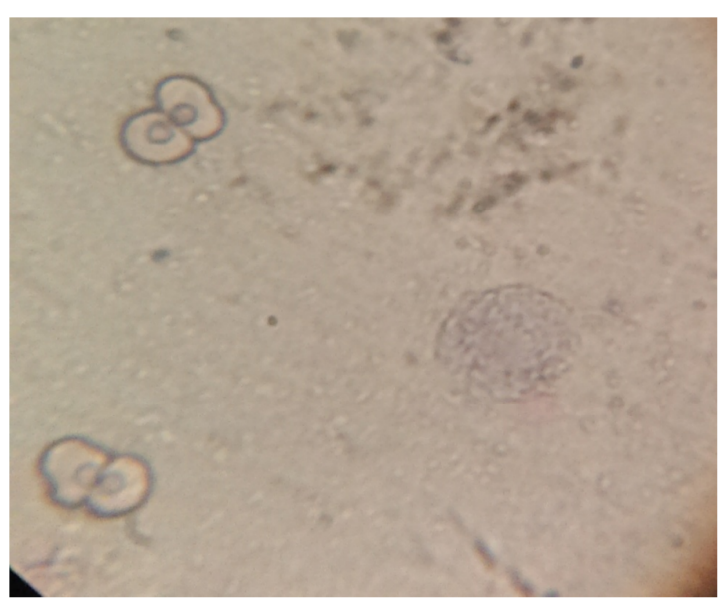

Binucleated x100

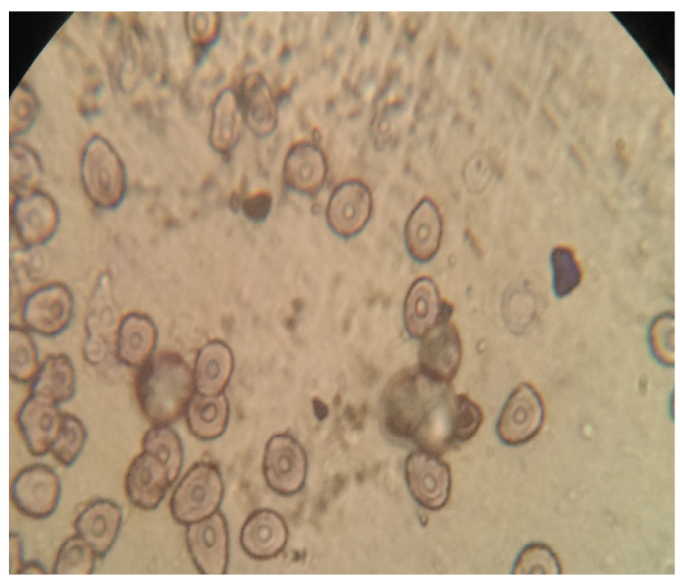

Normal Nuclei $x 100$

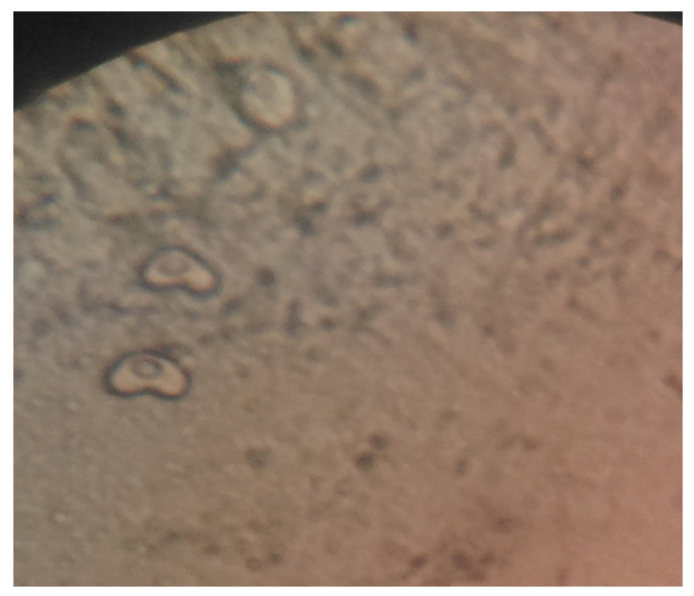

Lobed Nuclei x 100

Fig 5: Showing frequency of Micronucleus Assay (MN) 
Table 1: Analysis of Micronucleus Assay in Fish Species

\begin{tabular}{|l|c|c|c|c|c|c|c|}
\hline $\begin{array}{l}\text { Experimental } \\
\text { Animals }\end{array}$ & $\begin{array}{c}\text { Total no of } \\
\text { Micronucleus } \\
\text { and nuclear } \\
\text { abnormalities }\end{array}$ & Micronucleus & Binucleated & Lobed & Notched & Blebbed & Others \\
\hline $\begin{array}{l}\text { Laboratory } \\
\text { cultured } \\
\text { control }\end{array}$ & 45 & $2.50 \pm 0.50$ & $5.00 \pm 1.00$ & $5.00 \pm 2.00$ & $3.50 \pm 0.50$ & $3.50 \pm 1.50$ & $3.00 \pm 1.00$ \\
\hline $\begin{array}{l}\text { Oreochromis } \\
\text { niloticus }\end{array}$ & 190 & $17.00 \pm 2.00^{*}$ & $13.00 \pm 1.00$ & $10.00 \pm 1.00$ & $27.00 \pm 5.00^{*}$ & $11.50 \pm 1.50$ & $16.50 \pm 1.50^{*}$ \\
\hline $\begin{array}{l}\text { Sarotherodon } \\
\text { galilaeus }\end{array}$ & 145 & $14.00 \pm 2.00^{*}$ & $9.00 \pm 1.00$ & $7.50 \pm 0.50$ & $13.00 \pm 1.00$ & $20.50 \pm 3.50^{*}$ & $8.50 \pm 0.50$ \\
\hline Tilapia zilli & 147 & $10.50 \pm 0.50^{*}$ & $7.50 \pm 1.50$ & $13.00 \pm 2.00$ & $14.50 \pm 1.50$ & $11.50 \pm 2.50$ & $16.50 \pm 2.50^{*}$ \\
\hline $\begin{array}{l}\text { Positive control } \\
\text { Colchicine }\end{array}$ & 372 & $38.00 \pm 2.00^{*}$ & $26.00 \pm 3.00^{*}$ & $34.00 \pm 2.00^{*}$ & $26.00 \pm 2.00^{*}$ & $32.50 \pm 1.50^{*}$ & $29.50 \pm 2.50^{*}$ \\
\hline
\end{tabular}

Table 2: Frequencies, Mean and Standard Error of the Micronuclei and Other Abnormalities in Fish Samples

\begin{tabular}{lccc}
\hline $\begin{array}{l}\text { Experimental } \\
\text { Animals }\end{array}$ & $\begin{array}{l}\text { Total no of } \\
\text { Micronuclei Observed } \\
\text { Per species }\end{array}$ & $\begin{array}{l}\text { Other Nuclear } \\
\text { Abnormalities }\end{array}$ & Mean MN \pm SE \\
\hline $\begin{array}{l}\text { Laboratory cultured } \\
\text { control }\end{array}$ & 5 & 40 & $2.50 \pm 0.50$ \\
$\begin{array}{l}\text { Oreochromis } \\
\text { niloticus }\end{array}$ & 34 & 156 & $17.00 \pm 2.00^{*}$ \\
$\begin{array}{l}\text { Sarotherodon } \\
\text { galilaeus }\end{array}$ & 28 & 117 & $14.00 \pm 2.00^{*}$ \\
$\begin{array}{l}\text { Tilapia zilli } \\
\begin{array}{l}\text { Positive control } \\
\text { Colchicine }\end{array}\end{array}$ & 21 & 126 & $10.50 \pm 0.50^{*}$ \\
\hline
\end{tabular}

Table 3: Frequencies, Mean and Standard Error of Nuclear Abnormalities in Fish Samples.

\begin{tabular}{llll}
\hline $\begin{array}{l}\text { Experimental } \\
\text { Animals }\end{array}$ & $\begin{array}{l}\text { Total no of Nuclear } \\
\text { Abnormalities Per species }\end{array}$ & $\%$ Nuclear Abnormalities & $\begin{array}{c}\text { Mean } \\
\text { aberration } \pm \text { SE }\end{array}$ \\
\hline $\begin{array}{l}\text { Laboratory cultured } \\
\text { control }\end{array}$ & 45 & 4.5 & $15.00 \pm 0.50$ \\
$\begin{array}{l}\text { Oreochromis niloticus } \\
\text { Sarotherodon galilaeus }\end{array}$ & 190 & 19.0 & $63.33 \pm 5.00^{*}$ \\
$\begin{array}{l}\text { Tilapia zilli } \\
\begin{array}{l}\text { Positive control } \\
\text { Colchicine }\end{array}\end{array}$ & 145 & 14.5 & $48.33 \pm 12.00^{*}$ \\
\hline
\end{tabular}

*Statistically different from negative control $(\mathrm{p}<0.05)$

No of animal/group $=3$; Total no. of nuclei scored/concentration $=1000$

Result of analysis of micronucleus assay in Fish, frequencies, average and standard error of the micronuclei and other nuclear abnormalities in fish samples are presented in Table 1, 2 and 3 where similar trend was observed for induction of nuclear abnormalities which also showed that Oreochromis niloticus, Sarotherodon galilaeus and Tilapia zilli as well as the mean values $63.33 \pm 5.00,48.33 \pm 12.00$ and $49.00 \pm 13.00$ respectively were found to be statistically different from negative control $(\mathrm{p}<0.05)$.

The frequency of $\mathrm{MN}$ was determined following previously reported examination criteria (VeraCandioti, et al. 2013, Cavas- and K*onen, 2007; Vera-Candioti et al., 2010). Micronuclei appear chromatin masses resulting from chromosome fragments or intact whole chromosomes lagging behind in the anaphase stage of cell division and due mainly to exposure of cells to toxic substances (Figure 5).

In this study, results from micronucleus assay are presented in Table 2 which showed that there was significant induction of $\mathrm{MN}$ (statistically different from negative control $(\mathrm{p}<0.05))$ in the fish specimens Tilapia zilli, Oreochromis niloticus and Sarotherodon galilaeus. This could be due to exposure to different concentrations of heavy metals that may be present in the Asa River. From 6 and 7, the data of micronuclei showed the mean $\pm \mathrm{SE}$ of micronucleus indicated that it is statistically significant from negative control 
$(\mathrm{p}<0.05)$ in Oreochromis niloticus and Sarotherodon galilaeus.

This observation is consistent with studies that have previously shown that mutagens are prevalent in river water and mutagens could induce genotoxicity when tested for cytogenotoxicity using micronucleus test in fish (Lemosa et al., 2007) and Ames test (Valent et al., 1993; Vargas et al., 1993; Vargas et al., 1995;). These observed genotoxicities reported in this study poses a serious threat to food chain, fish reproduction, survival genomic instability and may lead to fish death.

Conclusion: This study clearly indicated significant bioaccumulation of heavy metals in the organs of the four fish species collected from Asa River. The study revealed that fish species that was cultured had very low bioaccumulation of heavy metals in their internal organs because they fed mainly on the feeds provided in the pond. In addition, heavy metals were more concentrated in the gills than other parts of the fish organs sourced because of relatively high potential for metal accumulation in the gills. Micronucleus test was used to assess the frequencies of micronucleus induction and nuclear and abnormalities among fish samples used in this study. Micronucleus assay used in this study clearly demonstrated that the fish samples and possibly other aquatic organisms in the Asa River are exposed to genotoxic substances such as metals which is evidence that the water is polluted. This is worrisome as it suggests that the fish samples in this river if consumed poses great health risk to humans due to presence of heavy metals in them beyond permissible limit.

Acknowledgment: The authors acknowledged Department of Industrial Chemistry and Zoology, University of Ilorin, Ilorin, Nigeria for making available laboratory equipment. Appreciation also goes to the Technologists of both departments for their technical supports in the course of this research work. Thanks also go to Prof R. G Snyman H.O.D; Department of Biodiversity and Conservation Management, Faculty of Applied Sciences, Cape Peninsula, University of Technology, Cape Town, South Africa for the editorial assistance. Authors wish to thank the University of Johannesburg for making library database available during the revision of this manuscript.

REFERENCES. Abdel-Baki, A.S; Dkhil, M.A; Al-Quraishy, S (2011). Bioaccumulation of some heavy Metals in tilapia fish relevant to their concentration in water and sediment of WadiHanifah, Saudi-Arabia. Afric. J. of Biotech. 10(13): 2541- 2547. doi: 10.5897/AJB10.1772.

Agah, H; Leermakers, M; Elskons, M; Fatemi, SMR; Baeyens, W (2009). Accumulation of Trace metals in the muscles and liver tissues of five fish species from the Persian Gulf. Environ. Monito Assess. 157: 499-514. doi: 10.1007/s10661-008-0551-8. Epub 2008 Oct 11.

Ai-Sabti, K; Metcalfe, CD (1995). Fish micronuclei for assessing genotoxicity in water. Mut. Res/Genetic Toxicol 343: 121-135. http://dx.doi.org/10.1016/0165-1218 (95)900780 .

Allen, P; Sin, Y. M; Wong, M. K1(988). Acute effect of mercuric intracellular GSH

Level and mercury distribution in the fish Oreochromis aurens. Bulletin Environ. Contam. and Toxico. 40: 17814. link.springer.com/article/10.1007\%2FBF018810 36

Ambedkar, G; Muniyan, M (2011). Bioaccumulation of some Heavy Metals in the selected five freshwater fish from Kollidam River, Tamilnadu, India. Archive of Applied cience Research. 3(3): 261-264.

(http://scholarsresearchlibrary.com/archive.html).

Ayllon, F; Garcia-Vazquez, E (2000). Induction of micronuclei and other nuclear abnormalities in European minnow, Phoxinus phoxinus and mollie, Poecilia latipinna an assessment of the fish micronucleus test. Muta. Res. 467: 177186.http://dx.doi.org/10.1016\%2fS13835718(00)00033-4

Baldisserotto, BMJ; Chowdhury, Wood, CM (2005). Effects of Dietary Calcium and Cadmium on Cadmium Accumulation, Calcium and Cadmium Uptake from the Water, and Their Interactions in Juvenile Rainbow Trout. Aquatic Toxicol 72(1): 99-117. http://dx.doi.org/10.1016/j.aquatox.2004.11.019.

Barron, MG; Albeke, S (2000). Calcium Control of Zinc Uptake in Rainbow Trout," Aquatic Toxicol.. Vol.50 (3):257-264. http://dx.doi.org/10.1016/S0166-445X (99)00099-5

Blasco, J; Rubio, J.A; Forja, J; Gomez-Parra, A; Estabiler, R (1998). Heavy Metals in some Fishes of the muglidae family from salt-pounds of Codiz Bay SW Spain. Ecotoxicol. and Environ. Res.. 1: 71-77.

Beetseh, CI;Abrahams J.O (2013). Dangers of Bioaccumulation of some heavy metals consumed in Sardine and Mackerel (ice Fish) in Benue State Nigeria. Civil and Environ. Res.. 3(5): 60-65. ISSN 2224-5790 (Paper) ISSN 2225-0514 (Online) 
Bhuvaneshwari, R, Mamtha, N, Selvam, P and Rajendran, R.B. 2012. Bioaccumulation of Metals in Muscle, liver, and Gills of Six commercial fish species at Anaikarai Dam of River Kaveri, South India. International Journal. of Applied biology and Pharmaceutical Technology. 3 (1): 8-14. http://www.ijabpt.com/
Bolognesi, C; Hayashi, M (2011). Micronucleus assay in aquatic animals. Mutagenesis. 26(1):205-13. doi: $10.1093 /$ mutage/geq073.

Burden, V.M; Sandheinrich, C.A; Caldwell, A. (1998). Effects of lead on the growth and alpha amino levulinic acid dehydrates activity of juvenile rainbow trout, Oncorhynchusmyk iss. Environ. pollut.. 101: 285-289. http://dx.doi.org/10.1016/S0269-7491(98)00029$\underline{3}$.

Bücker, AM; Carvalho, S; Conceição, M.B; AlvesGomes J.A (2012). Micronucleus test and comet assay in erythrocytes of the Amazonian electric fish Apteronotus bonapartii exposed to benzene. J.of Brazilian Soc. of Ecotoxicol.. 7 (1): 65-73. doi: 10.5132/jbse.2012.01.010.

Calabrese, EJ; Canada, AT; Sacco, C (1985). Trace Elements and Public Health. Annual Review of Public Health, 6: 131-146. doi: 10.1146/annurev.pu.06.050185.001023.

Deb, SS; Fukushima, T (1999). Metal in aquatic ecosystems: mechanisms of uptake, accumulation and release. Inter.J.of Environ. Studies. 56(3): 385.

doi: $10.1080 / 00207239908711212$.

Elleta, OAA, Adekola, FA and Omotosho, JS.2003. Determination of concentration of heavy

metals in two common fish species from Asa River, Ilorin, Nigeria. Toxicology and Environmental Chemistry. $\quad$ 85(1-3): doi: $10.1080 / 0277224031000106654$.

Eneji, IS; Ato, RS; Annune, PA (2011) Bioaccumulation of Heavy Metals in Fish (Tillapia Zilli and Clarias Gariepinus) Organs from River Benue North-Central Nigeria. Pakistan J.. of Anal.. Environ. Chem.. 12 (1\&2. http://www.ceacsu.edu.pk/PDF\%20file/Journal\% $20 \mathrm{Vol} \% 2012 \% 20 \mathrm{No}_{2} 201 \% 20 \& \% 202 / \mathrm{PJAEC}-$ 19072010-25.pdf

FAO / WHO (2011) Joint FAO/ WHO food standards programme codex committee on food and drugs 201.
Fatoki, O.S; Okoro, H.K; Adekola, F.A; Ximba, B.J; Synman, R.G (2012) Bioaccumulation of Metals in black mussels (Mytillus galloprovincialis) in Cape Town Harbour, South Africa, The Environmentalist. 32: 48-57. doi 10.1007/s10669-011-9370-5

Firat, O; Kargm, F (2007). Effects of metal (Zn, $\mathrm{Cd})$ and metal mixtures $(\mathrm{Zn}+\mathrm{Cd})$ on physiological and biochemical parameters in blood tissues of (Oreochromis niloticus) ( $\mathrm{PhD}$ thesis). PhD Thesis, Çukurova University, Turkey.

Ibrahim, A.T.H; Omar, H.M (2013). Seasonal Variation of Heavy Metals Accumulation in Muscles of the African Catfish Clatrias gariepinus and in River Nile water and sediments at Assiut Governorate, Egyptian $\mathrm{J}$ of Biol.and Earth Sci.. 3(2): B236-B248. http://jbes.strefa.pl.

Ibok, UJ; Udosen, ED; and Udoidiong, OM .(1989). Heavy metals in fishes from some steams in Ikot Ekpene area of Nigeria. Nigeria. Journal of Technology Research. 1-61.

Khail, M; Faragallah, H .2(008). Egyptian Journal of Aquatic Research. 38- 1

Kuroshima, R.1992. Comparison of cadmium accumulation in tissues between carp Cyprinascapia and red sea bream. Pagrus major, Nippon Suisan Gakkaistrim. 58: 1732-1242.

Lemosa, CT; Rodela PM; Terra NR; D'avila, DE Oliveira, CN; and Erdtmann, B. (2007). River water genotoxicity evaluation using micronucleus assay in fish erythrocytes. Ecotox. and Environ. Saf. 66: 391-401. doi: 10.1016/j.ecoenv.2006.01.004.

Linder, M.C., 2001. Copper and genomic stability in mammals. Mutation. Research. 475: 141-152. 10.1016/s0027-5107(01)00076-8.

Marcon, A. E; Ferreira, D. D. M;. de Moura., M. F. V; Campos, TF., do Amaral VS, Agnes-

Lima LF; Batstuzzo de Medeiros SR (2010).Genotoxic analysis in aquatic environment under influence of cyanobacteria, metal and radioactivity," Chemosphere 81: 773780. DOI: $10.1016 /$ j.chemosphere.2010.07.006

$$
\text { ? }
$$

Martinez, V., Creus, A., Venegas, W., Arroyo, A., Beck, J.P., Gebel, T.W., Surralles, J.,

Marcos, R., 2005. Micronuclei assessment in buccal cells of people environmentally exposed to arsenic in northern Chile. Toxicol. Lett. 155, 
319-327. http://dx.doi.org/10.1016/j.toxlet.2004.10.007

Meissner, R (2015). The governance of urban wastewater treatment infrastructure in the Greater Sekhukhune District Municipality and the application of analytic eclecticism. Int. J. Water Gov. 3 (2) 79-110. http://dx.doi.org/10.7564/14-IJWG55

Mendil, D; Uluozlu, O.D (2007). Determination of trace metals in sediment and five fish species from lakes in Tokat, Turkey. Food Chemistry. 101:739-745.

http://dx.doi.org/10.1016/j.foodchem.2006.01.05 $\underline{0}$.

Narayanan M; Vinodhini R (200)8. Bioaccumulation of heavy metals in organs of fresh water fish Cyprinus carpio (Common carp). Inter.J of Environ.Sci. and Technol.. 2 179-182. www.bioline.org.br/request?st08021

Nepomuceno, J.C; Ferrari, I; Spano, M.A; Centeno, A.J (1997). Detection of micronuclei

in peripheral erythrocytes of Cyprinus carpio exposed to metallic mercury. Environ. Mol. Mutagen. 30, 293-297. DOI: 10.1002/(SICI)1098-2280(1997)30:3<293::AID

- $\quad$ EM7>3.0.CO;2-M

Nwani, CD; Nagpure, NS; Kumar, R; Kushwaha, B; Kumar, P; Lakra, WS. (2013). Induction of micronuclei and nuclear lesions in Channa punctatus following exposure to carbosulfan, glyphosphate and atrazine. Drug Chem. Toxicol., Early Online 1-8. doi: 10.3109/01480545.2013.866138. Epub 2013 Dec 11.

Nwani, CD;Nagpure ,NS; Kumar, R; Kushwaha, B; Kumar, P; Lakra, WS (2011). Mutagenic and genotoxic assessment of atrazine-based herbicide to freshwater fish Channa punctatus (Bloch) micronucleus test and single cell gel electrophoresis. Environ. Toxicol. and Pharmacol. 31: 314-322. doi: 10.1016/j.etap.2010.12.001. Epub 2010 Dec 17.

Oguize, FA; Okosodo, CI (2008) Contribution of heavy metals in waste dumpsites from selected markets to the heavy metals load of Ikpoba River in Benin City, Nigeria. Journal of Field Aquat $\begin{array}{llll}\text { Studies. } & 4 & 51-56 . & \text { http//ww }\end{array}$ w.academicjournals.org/AJB

Oguize, FA; Okosodo, CI (1999). Concentrations of heavy metals in effluent discharges downstream of Ikpoba river in Benin City, Nig.Afr.. J of Appl Zool.. 2: 60-63. http//ww
w.academicjournals.org/AJB

Okoro, H.K; Fatoki, OS; Adekola, F.A; Ximba, B.J; Snyman, R.G (2013). Physico-chemical characteristics and One year monitoring of heavy metal pollution in Seawater from Cape Town Harbour and their Seasonal Variation, Fres. Environ.Bull., Germany. 22(10): 2855-2866

Okoro, H.K; Fatoki, OS; Adekola, F.A; Ximba, B.J; Snyman, R.G (2014a). Geochemical Assessment of Sediment in Cape Town Harbour, South Africa, Bulletinof Chemical Society of Ethiopia, 28(1)17-28. doi:http://dx.doi.org/10.4314/bcse.v28i1.3.

Okoro, H.K, Fatoki, OS; Adekola, F.A; Ximba, B.J ; Snyman, R.G. (2014b). Fractionation, Mobility and Multivariate Statistical Evaluation of Heavy Metals in Marine Sediments of Cape Town Harbour. Chemical Speciation and Bioavailability, St Albans, Herts, UK. 26(3): 126 -138 . http://dx.doi.org/10.3184/095422914X14038001 $\underline{06854}$

Otitoloju, AA (2002). Evaluation of join-action toxicity of binary mixtures of heavy metals against the mangrove periwinkle Tympanotonus Fuscatus Var radula (L.) Ecotoxicol. and Environ.. Saf.. 53(3):404-415. doi: $10.1016 / \mathrm{S} 0147-6513(02) 00032-5$

Olayinka, AS (2013) Seasonal Variations in Bioconcentration of Metals in Selected Organs of Clarias gariepinus from Asa River, Ilorin North Central Nigeria. International Journal. of Pure Science and Technology. 17(1) 22-29. www.ijopaasat.in Palermo, Ff; Risso We; Simonato, JD; and Martinez, CBR (2015)

Bioaccumulation of nickel and its biochemical and genotoxic effects on juveniles of the neotropical fish Prochilodus lineatus. Ecotoxicol.. and Environ.. Saf. 116:19-28. doi: 10.1016/j.ecoenv.2015.02.032 ?

Somero, GN; Chow, TJ; Yancey, PH;Snyder, C.B (1977). Lead accumulation rates in Tissues of the estuarineteleost fish, Gillichysmirabillis, salinity and temperature effects. Arch. of Environ.. Contam. and Toxicol.. 6 337-348. doi: 10.1007/BF02097774.

Rompala, JM; Rutosky FW; and Putnam, DJ (1984). Concentrations of Environmental Contaminants from Selected Waters in Pennsylvania," US Fish and Wildlife Service. Special Scientific Report, State College, Pennsylvania 35-38. www.sciencedomain.org 
Shivakumar, Ck; Thippeswamy B; Tejaswikumar MV; Prashanthakumara SM (2014) Bioaccumulation of Heavy Metals and its effects on organs of edible Fishes located in Bhadra River, Karanataka. International Journal. of Research in Fisheries and Aquaculture. 4 (2) 9098. http://www.urpjournals.com/.

Talapatra, S.N; Banerjee, S.K (2007). Detection of micronucleus and abnormal nucleus in

erythrocytes from the gill and kidney of Labeo bata cultivated in sewage-fed fish farms. Food Chem. Toxicol. $45 \quad$ (2), 210-215. DOI: 10.1016/j.fct.2006.07.022 ?

Tolbert, PE, Shy CM and Allen JW .1992. Micronuclei and other nuclear anomalies in buccal smears: methods development. Mutation Research $271 \quad 69-77$. http://dx.doi.org/10.1016/0165-1161(92)90033-I

Valent, GY; Sato MI; Coelho MC; Coimbra ${ }^{2}$ CA; Sanchez, PS (1993). Monitoring Sao Paulo state rivers in Brazil for mutagenic activity using the Ames test. Environ. Toxicol.. Water Qual. 8 371-381.

Vargas, VMF; Motta, VEP; and Henriques, JAP (1993). Mutagenic activity detected by the

Ames test in river water under the influence of petrochemical industries. Mutation. Res. 319: 31-45. http://dx.doi.org/10.1590/S141547571998000200013

Vargas, VMF; Guidobono RR; Jorda O C; Henriques AP (1995). Use of two short-term tests to evaluate the genotoxicity of river water treated with different concentration/extraction procedures. Mut. Res.. 343: 31-52. doi: 10.1016/0165-1218(95)90060-8

Vera-Candioti, J; Soloneski, S; Larramendy, ML (2013). Evaluation of the genotoxic and cytotoxic effects of glyphosate-based herbicides in the ten spotted live-bearer fish Cnesterodon decemmaculatus (Jenyns, 1842). Ecotoxico. and
Environ Safety 89: 166-173. DOI:

10.1016/j.ecoenv.2012.11.028

Vera-Candioti, J; Soloneski, S;Larramendy, ML (2010) Genotoxic and cytotoxic effects of the formulated insecticide Aficidas on Cnesterodon decemmaculatus (Jenyns, 1842) (Pisces:Poeciliidae).Mutat.Res.703:180-186. www.ubiobio.cl/miweb/webfile/media/194/v/v20 -1/8.pd

Vutukuru, S.S. (2005). Acute effects of hexavalent chromium on survival oxygen consumption, haematological parameters and some biochemical profiles of the Indian Major carp, Labeo rohita. Inter. J. of Environ.. Res.. and Public Health. 2 :456-463. www.ncbi.nlm.nih.gov/pubmed/16819101.

Yadav, K.K; Trivedi, S.P (2009): Sublethal exposure of heavy metals induces micronuclei in fish, Channa punctatea. Chemosphere 77: 14951500 .

doi: 10.1016/j.chemosphere.2009.10.022?

Yousafzai, AM; Siraj M;Ahmad, H; Chivers, DP. (2012). Bioaccumulation of Heavy Metals in Common Carp: Implications for Human Health. Pakistan J. of Zoology. 44(2):489-494. http://dx.doi.org/10.1007/s10661-016-5248-9

Yousafzal, A.M; Shakoori, A.R. (200)6.

Bioaccumulation of chromium, nickel, leads, copper and zinc in the Tor putitora as an indicator of the presence of heavy metals loads in River Kabul. Pakistan J. of Zool.. 4:341

347.eurekamag.com/research/012/948/01294870 7.php

Zhang, Z; HE, L; LI, J; WUZB. (2007). Analysis of Heavy Metals of Muscle and Intestine Tissue in Fish-in Banan Section of Chongqing from Three Gorges Reservoir, China. Polish J. of Environ. Studies, 16(6):949-

58.www.pjoes.com/index.php? $s=a b s \_i d \& i d=200$ 7160621 